\title{
Diminutives: Exceptions to Harmonic Uniformity
}

\author{
Péter Rebrus \\ Hungarian Academy of Sciences \\ prebrus@gmail.com \\ Péter Szigetvári \\ Eötvös Loránd University \\ szigetvari@elte.hu
}

Received: February 25, 2016

Accepted: June 22, 2016

\begin{abstract}
Front-back harmony in Hungarian is governed by the root of words: it disregards suffixes in most cases. That is, a back-vowelled root (B) followed by any number of neutral-vowelled suffixes $(\mathrm{N})$ will take a back-vowelled suffix $(\mathrm{B}+\mathrm{N}+\mathrm{N}+\mathrm{B})$, but a root with a back vowel followed by several neutral vowels is possibly followed by a front-vowelled suffix $(\mathrm{F})$ : $\mathrm{BNN}+\mathrm{F} / \mathrm{B}$. We call this Harmonic Uniformity. This is respected even in truncated stems: $N B \rightarrow N<B>+N+B$, although NN stems practically never take a back suffix $(N N+F)$. Diminutive forms are the only exceptions to this pattern. We claim that this is so, because diminutive forms are much more loosely related to their "base" than is the case with any other types of suffixation.
\end{abstract}

Keywords: morphology; vowel harmony; Hungarian; diminutives; truncation

Resum. Diminutius: excepcions a la uniformitat harmònica

L'harmonia anterior-posterior en hongarès és regida per l'arrel dels mots: en la majoria de casos no té en compte els sufixos. És a dir, una arrel amb una vocal posterior $(\mathrm{P})$ seguida per qualsevol nombre de sufixos amb una vocal neutral $(\mathrm{N})$ prendrà un sufix amb una vocal posterior $(\mathrm{P}+\mathrm{N}+\mathrm{N}+\mathrm{P})$, però una arrel que contingui una vocal posterior seguida de diverses vocals neutrals pot anar seguida d'un sufix amb una vocal anterior (A): $\mathrm{PNN}+\mathrm{A} / \mathrm{P}$. Anomenem aquest efecte Uniformitat Harmònica. Aquesta es respecta fins i tot en radicals truncats: $\mathrm{NP} \rightarrow \mathrm{N}<\mathrm{P}>+\mathrm{N}+\mathrm{P}$, encara que els radicals $\mathrm{NN}$ pràcticament mai no prenen un sufix posterior $(\mathrm{NN}+\mathrm{A})$. Les formes diminutives són l'única excepció a aquest patró. Proposem que la raó és que les formes diminutives estan relacionades a la seva «base» d'una manera molt més laxa que en qualsevol altre tipus d'afixació.

Paraules clau: morfologia; harmonia vocàlica; hongarès; diminutius; truncament

\section{Table of Contents}

1. Vowels and harmony in Hungarian

2. Harmonic uniformity

3. Truncation

4. Diminutives
5. Diminutives and their roots

6. Diminutives and harmony

7. Conclusions

References 
In a nutshell the problem we are concerned with is the following. The back-harmonic root ne:ma 'mute' loses its second vowel when suffixed: ne:mi:t 'make mute'. Yet, this stem remains back-harmonic: ne:mi:tanak 'make mute-3PL'. The back-harmonic root e:va, a name, also loses its second vowel in its diminutive form: e:vi. This stem, however, is front-harmonic: ervinek 'Eva-DIM-DAT'. Why should the two stems be different?

Diminutive forms are unique in the morphology of Hungarian. Although truncation is not only applied in the case of diminutive formation, but also in the case of various other morphological operations, it is only in the case of diminutives that the harmonic properties of words may change. We submit that this is due to the facts that (i) diminutive formation is not entirely productive, (ii) truncation is potentially more radical in diminutive formation than in any other case, (iii) the semantic bond between a word and its diminutive form is weaker than in other comparable word pairs, therefore (iv) diminutive forms are not "derived" (i.e. they do not have the morphological structure X+DIM), but they can be treated as (monomorphemic) roots on their own right. Since the harmonic properties of words are influenced by their morphological complexity, diminutives behave exceptionally in appearing to be morphologically complex, but behaving — at least with respect to vowel harmony - as morphologically simplex forms.

We first introduce the vowel inventory of Hungarian ${ }^{1}$ and the basics of front/ back harmony, with special emphasis on the front unrounded (i.e. the neutral) vowels. We then show what harmonic uniformity means: in any noncompound word, the root morpheme's harmonic property is inherited by the whole word. The next section looks at morphological operations that involve the truncation of the last vowel of the word, and the influence of truncation on vowel harmony. The most extensive part of the paper discusses the many ways diminutives are formed in Hungarian. We argue that a templatic diminutive word is a root: in many respectsmost notably, with regard to vowel harmony - it behaves as morphologically simplex. ${ }^{2}$ Our main arguments for this claim are given in the last but one section.

\section{Vowels and harmony in Hungarian}

Hungarian has root-governed front/back harmony, i.e. a root ${ }^{3}$ with a front vowel is typically followed by suffixes containing front vowels and a root with a back vowel is typically followed by suffixes containing back vowels (for a recent general survey, as well as references to earlier accounts see Törkenczy 2011). The vowel inventory is presented in (1).

1. In this paper "Hungarian" means standard Hungarian. In order to indicate morphemes clearly, we give fairly broad transcriptions (e.g. we ignore voicing assimilation and productive hiatus filling).

2. Diminutives are simplex as far as vowel harmony is concerned. However, such words do sometimes contain consonant clusters that are otherwise unprecedented within a morpheme: e.g. køstfi 'thanksDIM' (< køsønøm). Yet, as will be shown below, other diminutives even simplify well-formed morpheme-internal consonant clusters.

3. In this paper we use the term root for 'monomorphemic stem', i.e. in a form made up of X followed by two suffixes $\mathrm{Y}$ and $\mathrm{Z}, \mathrm{X}$ is the root of $\mathrm{XYZ}$ (and of $\mathrm{XY}$ ), and $\mathrm{XY}$ is the stem of $\mathrm{XYZ}$. 
(1) The vowel inventory of Hungarian

\begin{tabular}{|c|c|c|c|c|c|c|}
\hline \multicolumn{2}{|l|}{$\begin{array}{l}\text { front unrounded, } \\
\text { aka neutral }\end{array}$} & \multicolumn{2}{l|}{ front rounded } & \\
\hline i & i: & y & y: & u & u: & high \\
\hline- & e: & $\varnothing$ & $\varnothing:$ & o & o: & mid \\
\hline$\varepsilon$ & - & - & - & a & a: & low \\
\hline
\end{tabular}

Short and long vowels can be paired. The pairs are both phonetically similar (almost identical in the case of high vowels, rather different in the case of the low $\varepsilon /$ mid e: and the low a/a: pairs - as the symbols used here show) and morphologically related. All the short/long pairs participate in various morphological alternations: e.g. hi:d 'bridge' $\sim$ hid-ak 'bridges', y:r 'space' $\sim$ yr-yl 'become

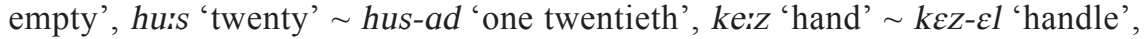
tevE 'camel' $\sim$ teve:- $t$ 'camel-ACC', nø: 'grow' $\sim$ nøv- $\varepsilon$ l 'increase', lo: 'horse' $\sim$ lov-a 'horse-3SGPOSS', na:r 'summer' nar-al 'go on holiday', pata 'hoof' $\sim$ pata:- $\int$ 'hoofed'. This justifies coupling $\varepsilon$ and e: despite their height difference. The height difference of the two vowels, however, cannot be ignored: it plays a role in the so-called height effect observed in neutral vowels, which we will briefly discuss below.

We present vanilla cases of front/back harmony in (2) using the sublative suffix $-r a / \varepsilon$.

(2) Front/back harmony

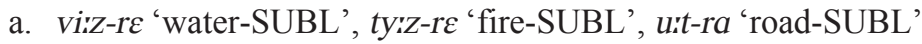
b. ke:z-re 'hand-SUBL', Jør-re 'beer-SUBL', bor-ra 'wine-SUBL'
c. tzj-re 'milk-SUBL', vaj-ra 'butter-SUBL', ha:j-ra 'fat-SUBL'

Besides front/back harmony, we can also observe rounding harmony in Hungarian. This is more limited than front/back harmony and it affects only a small number of suffixes (e.g. vi:z-hez 'water-ALLAT', ty:z-høz 'fire-ALLAT', u:t-hoz 'road-ALLAT'). In this paper we ignore rounding harmony.

\subsection{Neutral vowels}

The front unrounded vowels in (1) are labelled neutral. This is justified by the behaviour of these vowels. Various types of disharmony characterize neutral vowels. ${ }^{4}$ Invariant suffixes - suffixes with a vowel that does not alternate due

4. The examples here and in the subsequent part contain the "totally" neutral vowels $i$, $i$ : and e:, The "partially" neutral behaviour of the low vowel $\varepsilon$ will be mentioned in $\S 1.2$. 
to vowel harmony - typically contain a neutral vowel. Some examples are given below. The adjectival $-i$ is shown in (3a), the possessive -e: in (3b), the infinitival $-n i$ in $(3 \mathrm{c})$, and the agentive $-i: t$ in $(3 \mathrm{~d})$.

(3) Invariant suffixes containing a neutral vowel
a. $v i(:) z-i$ 'watery', ty(:)z-i 'fiery', $u(:) t-i$ 'road-ADJ'
b. vi:z-e: 'water-POSS', ty:z-e: 'fire-POSS', u:t-e: 'road-POSS'
c. vin-ni 'take-INF', ty:z-ni 'staple-INF', un-ni 'be bored-INF'
d. diss-i:t 'decorate', yr-i:t 'make empty', u:j-i:t 'make new'

Another type of disharmony that involves neutral vowels is standardly called transparency. Transparent vowels are invisible to vowel harmony, which accordingly works as if these vowels were not present. We give examples for back+neutral roots in (4a): these take back suffixes, and for front + neutral roots in (4b): these take front suffixes.

(4) Transparency of neutral vowels

a. fakirr-ra 'fakir-SUBL', kafte:j-ra 'castle-SUBL, ale:l-va 'faint-PART'

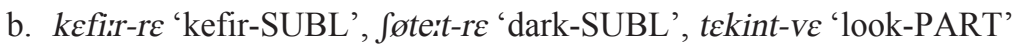

The most spectacular type of disharmony is called antiharmony. Antiharmony is restricted to monosyllabic roots containing a front unrounded, i.e. neutral vowel. Examples for such roots are provided in (5a). The roots in (5b) are "normal" in that they take front suffixes as expected of a front-vowelled root. They are given for comparison.

(5) Antiharmonic roots

a. Sirr-ra 'grave-SUBL', he:j-ra 'peel-SUBL', irt-va 'destroy-PART'

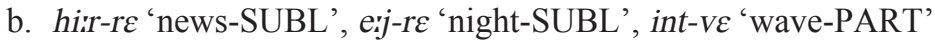

There is a very limited set of bisyllabic roots that are variably antiharmonic: ferrfi-ra/ $\varepsilon^{5}$ 'man-SUBL' and $d \varepsilon r e r k-r a / \varepsilon$ 'waist-SUBL', and fully so with vowelinitial suffixes: ferrfi-ak 'man-PL', derck-am 'waist-1SGPOSS'. The fact that (almost) only monosyllabic roots may be unhesitatingly antiharmonic is named the polysyllabic split by Rebrus \& Törkenczy (2015). ${ }^{6}$

5. Cf. the archaic variant ferfiu(:) 'man'.

6. In some dialects there are further examples for polysyllabic antiharmonicity, e.g. pifil-ok 'pee-1SG', fikti:v-an 'fictively', see Blaho \& Szeredi 2013. 


\subsection{Gradient neutrality}

As shown in (1), there are four neutral vowels in Hungarian, $i, i$, ex, and $\varepsilon$. It has been observed that these four vowels are not equally neutral (e.g. Kontra \& Ringen 1986, Siptár \& Törkenczy 2000: 70ff). Bisyllabic roots with a back vowel followed by $i$ or $i$ ( $(\mathrm{B} i$, we use $\mathrm{B}$ for any back vowel) practically always take the back variant of suffixes (e.g. fakirr-ra 'fakir-SUBL'; absint-ra/E 'absinthe-SUBL' is a rare counterexample). Ber roots are not uniform, most are common with a back variant (e.g. kafte:j-ra 'castle-SUBL'), but some are variable (e.g. sate:n-ra/c 'satin-SUBL'). Finally, $\mathrm{B} \varepsilon$ roots are usually variable (e.g. fot $\varepsilon$ l-re/a 'armchair-SUBL') and some take only the front variant of suffixes (e.g. ha:rem-re 'harem-SUBL'). As can be verified, the higher a neutral vowel, the "more transparent" it is. This phenomenon is called the height effect by Hayes \& Cziráky Londe (2006).

The number of neutral (i.e. transparent) vowels in the string across which harmony spreads also affects the degree of transparency. As we have seen Bi roots almost exclusively take the back variant of suffixes, but Bii roots are usually variable and perhaps tilt towards taking the front variant (e.g. alibi-re/a 'alibi-SUBL', kolibri-re/a 'hummingbird-SUBL', klarine:t-re/ a 'clarinet-SUBL'; but again note the exclusively back harmonic a:prilif-ra 'April-SUBL'). Various combinations of neutral vowels yield different results (e.g. bakelit-re/a 'bakelite-SUBL' vs kabinet-re/*a 'cabinetSUBL'), but we need not go into further detail here (see Forró 2012 for more data). This phenomenon is called the count effect by Hayes \& Cziráky Londe (2006).

The four neutral vowels are also different in their distribution in suffixes. The two highest ones, $i$ and $i$, do not alternate in suffixes with a back counterpart: suffixes containing these vowels are invariant. ${ }^{7}$ The mid e: occurs in both invariant suffixes (e.g. -e: 'POSS', -e:k 'FAM.PL', -ke:nt 'ESSIV/FORMAL', -ne:k '1SG. COND', ) and harmonizing ones (e.g. -ne:l/-na:l 'ADESS', -ve:/-var 'TRANSLAT',

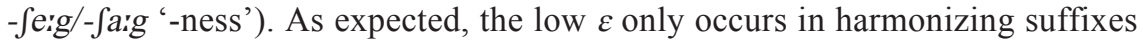
(e.g. -re/-ra 'SUBL', -ben/-ban 'INESS'). (For a list of suffixes, see Rebrus 2000: $775,777 \mathrm{ff}$, for a more detailed discussion of the graduality of vowel neutrality see Törkenczy \& al 2013.)

\section{Harmonic uniformity}

We have seen that the harmonic class of a monosyllabic root containing a neutral vowel is practically unpredictable. In the case of roots containing $i$ or $i$ : there is no statistical majority: about half of these roots take the back, the other half the front variant of suffixes. The other two neutral vowels, e: and $\varepsilon$, are usually front harmonic with a few cases of back harmony. Thus, at least in the case of monosyllabic neutral-vowel roots we have to assume that these are lexically assigned to a harmonic class (front or back).

7. There is one suppletive suffix in which $i$ alternates, the verbal 3SG.DEF -i/-ja: e.g. kerr-i 's/he asks for it' vs var-ja 's/he waits for it'. Note that even here $i$ does not alternate with its high counterparts, $y$ and $u$, despite the fact that these vowels are available in the inventory. So the $\varepsilon / \varnothing / o$ alternation is not parallelled by any $i / y / u$ alternation. 
The harmonic class of a word is identical to the harmonic class of its root, be that root bound or free. In most cases this makes no difference, since suffixes following the root agree with it in harmony. But the fact that harmony is determined by the root is visible if a root of the back-harmonic class is suffixed with invariant neutral-vowel suffixes. Consider the following examples.

(6) The harmonic class of suffixed words
a. hi:d-ra 'bridge-SUBL', hird-e:-ra 'bridge-POSS-SUBL'
b. vi:z-re 'water-SUBL', vi:z-e:-re 'water-POSS-SUBL'
c. in-na 'drink-3SG.COND', in-ni-ja 'drink-INF-3SG'
d. vin-ne 'take-3SG.COND', vin-ni-je 'take-INF-3SG'
e. pa:riz-ra 'Paris-SUBL', pa:riz-i-ra 'Paris-ADJ-SUBL'
f. hamif-ak 'fake-PL', hamif-itt-ok 'fake-VERBAL-1SG'
g. kolibri-ra/re 'hummingbird-SUBL', kolibri-e:-ra/re 'hummingbird-POSS-SUBL'
h. hotel-ra/re 'hotel-SUBL', hotel-e:-ra/re 'hotel-POSS-SUBL'
i. ha:rem-re 'harem-SUBL', ha:rem-e:-re 'harem-POSS-SUBL'

In (6a) we see that the bisyllabic stem hirder is antiharmonic. We have claimed above that apart from two bisyllabic roots, all antiharmonic roots consist of a single syllable, this was referred to as the polysyllabic split. The examples above do not violate the polysyllabic split, since hirde: is not a single morpheme. The stem hi:de: takes the back variant of suffixes because its root, hird, also takes the back variant of suffixes. This situation is perfectly regular in Hungarian for both nouns, like hi:d, and verbs, like $i C_{-} 8$ 'drink' as shown in (6c). If a root selects the front variant of suffixes, like vi:z in (6b) and viC- 'take' in (6d), then the suffixed forms of these roots also select the front variant of suffixes. The bisyllabic roots parriz, in (6e), and hamif, in (6f), take the back variant, as almost all Bi roots do. When suffixed by the invariant neutral-vowelled adjectival suffix $-i$ or verbal suffix -i:t, the harmonic class remains the same: parrizi 'Parisian' and hamifit 'forge' are not variable in their harmonic choice, like other monomorphemic Bii roots would be. As (6g) shows the vacillating Bii root, kolibiri remains vacillating after the addition of a neutral suffix, unlike a Biii or Biie: root, which is much more likely to attract a front suffix. Similarly, the vacillating root of $(6 \mathrm{~h})$ remains vacillating with the invariant neutral-vowelled possessive suffix, while the nonvacillating root of (6i) remains nonvacillating. We call this phenomenon harmonic uniformity (Rebrus \& Törkenczy 2015).

8. The stem of 'drink' and 'take' contains a variable consonant: is-ok 'drink-1SG', in-ne:k 'drink1SG.COND', it-tam 'drink-1SG.PAST', if-ak 'drink-1SG.IMP', iv-o: 'drink-PART'. We mark this consonant by $\mathrm{C}$. There are also forms in which this consonant is missing, e.g. i-hat 'may drink'. 
Harmonic uniformity is very pervasive in Hungarian vowel harmony. The bound root ind- 'start' is back harmonic (cf. ind-ul 'start-MEDIAL') and preserves this property irrespective of how many neutral (i.e. front-vowelled) suffixes are added: ind-i:t-va 'start-ACTIVE-PART', ind-i:t-e:k-ra 'motive-SUBL', ind-i:t-e:ke:-ra 'motive-POSS-SUBL' and ind-i:t-e:k-e:-i-ra 'motive-POSS-PL-SUBL'. We do not observe any variation at all in these cases. The word indiste:ke:i contains five phonetically front vowels and yet is invariably back harmonic. This is because its root, ind-, is antiharmonic, hence it will take the back variant of any variable suffix that follows it. Compare this with the front harmonic diss 'ornament', where after the same neutral suffixes, we find the front variant of variable suffixes: dirs-i:t-e:ke:-i-re 'decoration-POSS-PL-SUBL'.

\section{Truncation}

Hungarian morphology is mostly concatenative (for its limits, the flectional phenomena in the verbal paradigm, see Rebrus 2005). The alternations across morpheme boundaries involve voicing and other types of assimilations, as well as truncation $^{9}$ of the stem, or in some cases the suffix. Stem truncation usually involves the loss of the last vowel of the stem, which may be word-final or not. Representative examples are given in (7).

(7) Truncation of the last vowel of the stem

a. barna 'brown', barn-ul 'become brown', barn-i:t 'make brown'

b. ferde 'oblique', ferd-yl 'become oblique', ferd-i:t 'make oblique'

c. domboru(:) 'convex', dombor-od-ik 'become convex-3SG', dombor-ist 'make convex'

d. $k \varepsilon \int \varepsilon r y(:)$ 'bitter', $k \varepsilon \int \varepsilon r-\varepsilon d-i k$ 'become bitter-3SG', $k \varepsilon \int \varepsilon r-i: t$ 'make bitter'

e. fako: 'pale', fak-ul 'become pale', fak-ist 'make pale'

f. torok 'throat', tork-a 'throat-POSS3SG', tork-of 'gluttonous'

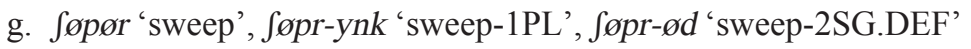

The words in (7a-e) illustrate the loss of word-final vowels. A truncated wordfinal vowel is typically a or $\varepsilon$, as in $(7 \mathrm{a}, \mathrm{b})$, but the truncation of $u(:), y(:)$, and $o:$ also occurs as shown in $(7 \mathrm{c}, \mathrm{d}, \mathrm{e})$. Truncated stems must be at least two syllables

9. Anonymous reviewers suggest that the deletion of a single vowel should not be referred to as truncation, this term should be reserved for the deletion of longer portions of the base. As we will see, diminutive truncation also often involves the deletion of a single vowel. Using different terms for the two types only because they have a different effect on the harmonic properties of the stems seems to be begging the question. So following Alber \& Arndt-Lappe (2012) we use the term truncation for both types. Diminutive truncation is templatic, all other kinds of truncation in Hungarian are subtractive. 
long (but they might be longer, (7c, d)), the only vowel of a word is never lost. Word-internal truncation is also only possible in words that are at least two syllables long and end in -VCVC. The vowel that is lost in word-internal truncation is always short and predominantly $\varepsilon, \varnothing$, or $O$, although any of the other short vowels also occurs in one or two examples each (Siptár \& Törkenczy 2000: 215).

Truncated roots provide further evidence for harmonic uniformity. Bisyllabic roots containing a neutral vowel followed by a back vowel are back harmonic, $(8 \mathrm{a}$, c), those containing a neutral vowel followed by a front vowel are front harmonic, $(8 \mathrm{~b}, \mathrm{~d}, \mathrm{e})$, as expected.

(8) Neutral+back and neutral+front stems

a. be:na 'lame', be:na-Ja:g 'lame-ness'

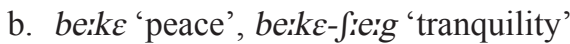

c. pisok 'dirt', pisok-ra 'dirt-SUBL'

d. iker 'twin', iker-re 'twin-SUBL'

e. e:ber 'alert', e:ber-re 'alert-SUBL'

In the roots in (8) and their ilk it is the final vowel that explicitly shows the harmonic class they belong to. If this vowel is truncated there remains no phonetic representative of the harmonic class, i.e. the harmonic class of be:n-and be:k-cannot be read off their phonetic shape. Harmonic uniformity predicts, however, that their harmonic class does not change, and this is indeed so, as the examples in (9) show.

(9) Truncated neutral+back stems
a. be:n-i:t-unk 'paralyse-1PL'
b. be:k-i:t-ynk 'make peace-1PL'
c. pisk-it-unk 'make dirty-1PL'
d. ikr-ek 'twin-PL'
e. e:br-en 'awake'

Roots whose back vowel is truncated leaving only a neutral vowel behind look and behave like monosyllabic antiharmonic roots, as shown in (10).

(10) Comparison of truncated and antiharmonic roots

a. Sima 'smooth', Sim-ul 'become smooth', Sim-itt-unk 'make smooth-1PL'

b. hi:d 'bridge', hid-ak 'bridge-Pl', hi:d-er-ra 'bridge-POSS-SUBL'

After this brief introduction of those properties of front/back harmony that are relevant to our discussion, we proceed to a survey of types of diminutive formation in Hungarian. 


\section{Diminutives}

Like in many other languages, there are several ways of forming diminutives ${ }^{10}$ in Hungarian and many types of diminutive forms are templatic (cf. Alber \& ArndtLappe 2012). The diminutive suffix - $(V) t f k \varepsilon /-(V) t f k a$ is productive and has no templatic requirements, it can be added at the end of nominals of any length, the vowel before the suffix appears after consonant-final stems: ${ }^{11}$ e.g. gnu: 'gnu' $\sim$ gnu'-t $f k a$, tEvE 'camel' $\sim$ tever-tfke, kenguru 'kangaroo' $\sim$ kenguru-tfka, elefa:nt 'elephant' $\sim$ elefa:nt-otfka, zira:f 'giraffe' zira:f-otfka, majom 'monkey' $\sim$ majm-otfka. This diminutive suffix follows patterns that many other suffixes do in Hungarian, including the lengthening of the stem-final $\varepsilon$ (and $a$ ) or the truncation of the last vowel. Compare the same stems combined with the plural suffix: gnu:-k, $t \varepsilon v e:-k$, kenguru-k, elefa:nt-ok, zira:f-ok, majm-ok.

Another diminutive suffix, $-k \varepsilon /-k a$ is less free in its distribution: it cannot be productively added to monosyllables or to stems ending in $a$ or $\varepsilon /$ e: So we can have e.g. $\varepsilon m b \varepsilon r$ 'man' $\sim \varepsilon m b \varepsilon r-k \varepsilon$, darab 'piece' $\sim$ darab-ka (in fact, $\varepsilon m b \varepsilon r-\varepsilon t f k \varepsilon$, darab-otfka are also possible, if rarer diminutive forms), but not alma 'apple' *alma:ka (only alma:tfka) or ke:z 'hand' *ke:z-ke (only kezetfke). Monosyllables must either take the unrestricted $-(V) t f k \varepsilon /-(V) t f k a$ suffix or augment the stem: sø:r '(body) hair' $\sim$ sø:r-øtfke (or sørri-ke, with an augment to be long enough), rab 'prisoner' rab-otfka, pa:l pa:l-otfka (or pali-ka). ${ }^{12}$

\subsection{Monosyllabic diminutives}

Other diminutive forms are more restrictively templatic: they set the exact size of the output. The most common diminutive template is bisyllabic, but there seems to exist a monosyllabic and a trisyllabic template too. Benua (1995) shows several cases of truncated diminutives (and other categories) that violate phonotactic constraints regulating other forms of the given language. Truncated diminutives of Hungarian do not show many signs of such misbehaviour, in fact they exhibit the harmonic behaviour of "normal" monomorphemic stems, unlike other morphologically complex stems, which inherit the harmonic properties of their root.

10. In this paper we do not distinguish between diminutive and hypocoristic forms, since with a few exceptional cases, the two types of forms can both be produced applying the mechanisms described in this section.

11. We are not going to give a gloss for diminutive forms. Any other unglossed form is either a name, or has been glossed earlier.

12. There are archaic diminutives that do not obey this requirement, e.g. bø:r 'skin', bø:r-ke 'bacon skin', lap 'sheet' lap-ka 'flan/chip', sa:l 'thread' sa:l-ka 'splinter', hu:r 'string, intestine' hur-ka 'black pudding'. This pattern is not productive, and the meaning relationship between the stem and its "diminutive" form is not clear. The regular, semantically transparent diminutive forms are bø:r børr-øtfke 'skin-DIM', lap lap-otfka 'sheet-DIM', sa:1 sa:l-atfka 'thread-DIM', hu:r hu:r-otfka 'string-DIM'. Another set of archaic diminutives truncate the stem to a bisyllabic template: bori bor-ka, pani $\sim$ pan-ka, furi jur-ka, judit jud-ka, doroc: $a \sim d o r-k a$. This truncation is not obligatory: bori-ka, pan:i-ka, furi-ka, jutsi-ka, dorri-ka. Truncation is also possible at the end of longer forms: ilona ilon-ka, veronika veron-ka. (See Kiefer \& Ladányi 2000 for a somewhat different account of this suffix.) 
There aren't very many monosyllabic diminutives and they are mostly phatic elements: e.g. køsønøm '(I) thank you' køs(:) (also bisyllabic køsi), botfa:nat 'sorry' $\sim \operatorname{bot}$ (also bisyllabic botfi, botf $\varepsilon s$ ), $\varepsilon g e:\left\{:\right.$ :egedre reaction if someone sneezes $\sim \varepsilon g \int$, $o k \int i$ 'okay-DIM' $\sim o k \int, t f a(:) o$ : greeting $\sim t f a$. There are also nonphatic words with a monosyllabic diminutive: e.g. profes'or 'professor' $\sim$ prof(:), zuza/zuzan'a $\sim$ zu. Nevertheless, this type of diminutive formation seems rather marginal in Hungarian, compared to, for example, English (cf. Sue, Joe, Vic, Bill, Kate, doc, vet, lab, bro).

\subsection{Bisyllabic diminutives}

While monosyllabic diminutives have no fixed segments, the bisyllabic template ends in a fixed, albeit very variable set of endings: - $u,-u \int,-o^{\prime},-k o:,-t s o:,-o s,-a,-t s a$, $-t f a,-i,-i \int,-s i,-\int i,-t s i,-t f i,-\varepsilon k,-\varepsilon S,-\varepsilon^{13}$ (the last ending involves the gemination of the preceding consonant). Because of the size of the template, any word which is longer than a syllable must be truncated to give way for the ending of the template, which always includes a vowel. Using our native speaker's competence, we have collected representative examples in (11), arranged by the vowel they contain.

(11) Some examples of the bisyllabic diminutive template

i. $u$-diminutives

a. ge:za ge:z-u, apa 'father' $\sim$ ap-u, fizete: 'salary' fiz- $u$

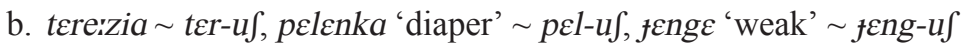

ii. $o$-diminutives

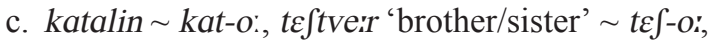
sendvitf 'sandwich' $\sim$ send-o:

d. ja:nof jan-ko', tztova:la:! 'tattoo' $\sim$ tet-ko', fesyltfe:g 'tension' $\sim$ fEs-ko:

e. ferents $\sim$ fe-tso', judit $\sim$ ju-tso', ke:gli 'flat' $\sim$ ke-tso:

f. biolo:gia 'biology' bi-os, matfka 'cat' $\sim$ matfk-os, filolo:guf 'philologist' or filozo:fuf 'philosopher' $\sim$ fil-os

iii. $a$-diminutives

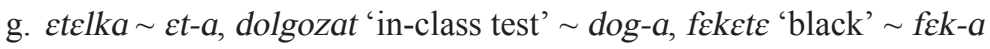
'African American'

h. ilona $\sim$ i-tsa, e:vi $\sim$ vi-tsa, laislo: $\sim$ la-tsa

i. ma:ria $\sim$ mar-tfa, borba:la $\sim$ bor-tfa, an:a $\sim$ an-tfa

13. Some of these diminutive endings are not productive, one example is - $\varnothing$;, which can only be added

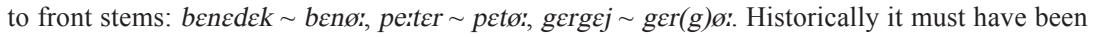
the front variant of the still productive diminutive ending -o: Similarly, we find dømøtør $\sim$ døme, domonkof $\sim$ doma, i.e. harmonizing $\varepsilon / a$, but of this pair, it is again only the back variant that is still productive. 
iv. $i$-diminutives

j. zolta:n $\sim$ zol-i, tørte:nelem 'history' $\sim$ tør-i, hu: 'meat' $\sim$ huf-i, undorito: 'disgusting' $\sim$ und-i

k. ju:lia $\sim$ jul-if, borba:la bor-if, andra: $\sim$ andr-if, atil:a $\sim$ at-if, a:braha:m a:br-if

1. fula $\sim$ fu-si, nu:l 'rabbit' $\sim$ nu-si, tfaj 'gal' $\sim t \int a j-s i$

m. miha:j mi-fi, ak(:)um(u)la:tor 'battery' ak- $\mathrm{ji}$, oke: 'okay' $\sim$ ok- $\int i$

n. jenø: jen-tsi, fudbal (earlier fodbal) 'football' fo-tsi, nø: 'woman' $\sim$ nø:-tsi

o. lajos $\sim$ laj-tfi, pulorver 'pullover' $\sim$ pul-t $f$ i, finom 'delicious' $\sim$ fin-t $f$ i, kira:j 'cool' $\sim$ kir-t $f$ i, unalmaf 'boring' $\sim$ un-t ffi

v. $\varepsilon$-diminutives

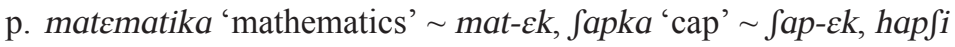
'chap' hap-ek

q. tfaba $\sim$ tfab-es, alkoholifta 'alcoholic' $\sim a l k-\varepsilon s$, kol(:)e:gium 'dorm' kol-ES

r. kalauz kal-:er 'conductor', kom(:)unifta 'communist' kom-:'er, jugdi:jaf 'pensioner' $\sim$ jug-'icr

We can see that there are many diminutive endings. Some stems may take more

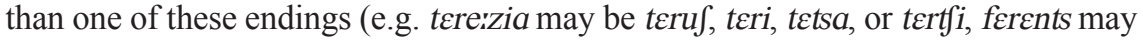
be fero', ferko', fetso', feri, or fertfi), but many stems only take one of them and in most cases it is unpredictable which one. In some cases we may detect a tendency to avoid homonymy, for example, reprezenta:tsio: aja:nde:k 'hospitality gift' $\sim$ repi

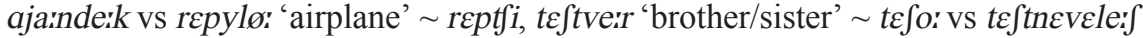
'PE' $\sim t \varepsilon f i$. Moreover, there are cases where the stems are homonymous and their diminutive forms are different: lokomoti:v loki name of a football team (DVSC) or loksi name of a rock band (Locomotiv GT). In other cases the diminutive forms are homonymous, e.g. sena can be a diminutive of sendvitf 'sandwich' or seme:t 'bastard' or untfi of unalma 'boring' or undori(:)to: 'disgusting', pino: of pimpong 'pingpong' or pintse 'cellar', gabi of both ga:bor and gabriel:a, beni may be a diminutive of bentse, benedek, benja:min, or bendegu:z.

We also cannot fully predict the extent of truncation in these templatic diminutive forms. The endings in (11) all involve a vowel, so in order to fit the bisyllabic template the second vowel of the word and everything that follows it has to be deleted. However, how much of the consonantal interlude between the first and the second vowel remains is only loosely governed by rules. Consonant plus liquid clusters are often simplified before the most common ending, -i: patritsia $\sim$ pati, henriet:a heni, miklo: $\sim$ miki, kupleraij 'brothel' $\sim$ kupi, imre $\sim$ imi, 
but imruf, ambruf ambi, but ambro:, alcksandra sandi, but sandra. ${ }^{14}$ There is variation in the case of other clusters: e.g. barbara $\sim$ barbi vs borba:la $\sim$ bori (not *borbi), dolgozat 'in-class test' $\sim$ doga or doli (not *dolga or *dolgi and not *dola or *dogi) vs olga olgi, borju(:) 'calf' $\sim$ botsi (not *bortsi) vs mairton $\sim$ martsi, zolta:n is usually zoli (rarely zolti), but zolt is usually zolti and only rarely $30 l i$.

The single vowel endings of the bisyllabic template are often preceded by a palatal consonant: pifti picu, pe:ter peca, zolta:n zoca, pa:l paja, sendvitf 'sandwich' or seme:t 'bastard' sena, pintse 'cellar' pino', vintfester 'hard disk' $\sim$ vipo', benzin 'gasoline' bena, benedek benuf, mertse:des car type $\sim$ merojo:. If the stem had a palatal consonant, it remains before $-i$ (e.g. ma:ca: $\int \sim$ maci, løc: 'tasteless drink' løci, nafmama 'grandmother' nafi, bonolult 'complicated' boni), but unlike before the other single vowel endings, replacing the consonant by a palatal is not common before $-i$, although some examples occur: e.g. faindor $\sim$ Sani, ${ }^{15}$ liter 'litre' lici.

The length of the root-initial vowel is also rather unpredictable. We find many examples where this vowel shortens: pa:l pali or palko', pe:ter $\sim$ peti or peca, ju:lia $\sim$ juli or julo', li:dia lidi, ti:mea $\sim$ timi, lo'ver $\int \varepsilon n$ 'horse race' $\sim$ lovi, ka:roj $\sim$ kares. In other cases we do not observe shortening: jo:zef jo:zi (but jotso: or jozo:), lo:ra:nd lo:ri, kla:ra kla:ri, be:la be:tsi, e:va ervi, pa:linka 'brandy' pa:les. In fact, there also are a few cases where the vowel seems to lengthen: hedvig $\sim$ he:di, Spetsia:lif 'special' Spertsi. Following van de Weijer (1989) we suspect that in these cases the diminutive forms are loans from German. Another apparent case of lengthening is farolta Jarri, but this form is also the diminutive of Jarra, which contains a long vowel.

To fit the bisyllabic template some words are truncated at their beginning, too. This is more common for, but not limited to vowel-initial words. Examples are given in (12).

(12) Initial truncation

a. albert $\sim$ bertsi, alfre:d $\sim$ fre:di, aleksandra $\sim$ sandi or $1 \varepsilon k s i,{ }^{16}$ an'u $\int \sim n u \int i$, ali: $\sim$ lizi, ambrus $\sim$ brufi

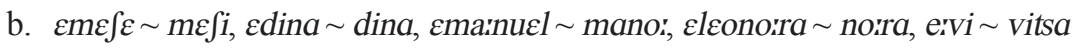

c. igna:ts $\sim$ na:tsi, ilona $\sim$ lontsi, imola $\sim$ moluf

d. $\varnothing d \varnothing n \sim$ døntsi

e. tsetsi:lia $\sim$ tsili, ferdina:nd $\sim$ na:ndi, bernadet: $\sim$ det:i, Stefa:nia $\sim$ fa:ni, marifka rifka, margit $\sim$ git'a, brigit' $a \sim$ git'a

14. Van de Weijer (1989) contends that this simplification always occurs when the cluster is not a possible "coda". This is not the case, there are several counterexamples: e.g. adrien adri, bodrof 'frilly' bodri dog's name, ugro: 'jumping' ugri rabbit's attribute.

15. It may be the case that fani is from Sana, which itself is a diminutive of fa:ndor and in which the palatal before $-a$ fits an attested pattern.

16. The male name fandor itself is a clipped form of aleksander. 
Besides initial truncation, the adding of phonetic material also occurs word initially. This is limited to a few vowel initial names, some of which are shown in (13).

(13) Labial prefixation
a. an:a $\sim$ pan:a, ifti $\sim$ pifti
b. andra:f/andor $\sim$ bandi, erze:bet $\sim$ bøzi

In fact, this type reflects a common reduplication pattern in which a word is repeated with the insertion of a labial consonant or the replacement of its first consonant by a labial: e.g. e:di (< e:def 'cute') e:diberdi, tfiga 'snail' tfigabiga, tsitsa 'cat' $\sim$ tsitsamitsa. For labial-initial stems the form is repeated at the beginning without the initial labial: pitsi 'small' itsipitsi, fintfi ( $<$ finom 'delicious') $\sim$ intfifintfi, pirul 'blush' $\sim$ irulpirul. In some cases this is also coupled by vowel change, front vowels in the first half, back vowels in the second half: e.g. mozog 'move' izegmozog, zene 'music' zenebona ${ }^{17}$ (cf. Sóskuthy 2012 and Patay 2015 for detailed surveys and analyses). In each case the second half begins with a labial, irrespective of whether it is the base or the reduplicant.

Diminutives are not restricted to nouns and adjectives. Verbs, even clauses may have diminutive forms. Examples are given in (14).

(14) Verbal diminutives

a. mutaf-d 'show-2SG.DEF.IMP' $\sim$ muti/muta, fifel-j 'listen' $\sim$ fiji/fifu

b. le:f sivef 'be (so) kind (=please)' le:fsi, ad(:) ide 'give-2SG.DEF.IMP here' adi

Yet another type of diminutive formation occurs only for given names, exceptionally for family names. This involves the reduplication of the first $\mathrm{CV}$ of the name, as the examples in (15a) show. The pairs in (15b) are phonologically less transparent diminutive forms, while $(15 \mathrm{c})$ shows family names exhibiting this process.

(15) Reduplicated diminutives
a. zolta:n $\sim$ zozo:, mo:nika $\sim$ momo:, pe:ter $\sim$ pepe, veronika $\sim v \varepsilon v \varepsilon$, laura/ lajo $\sim$ lala, silard/silvia sisi, lujza lulu, zita $\sim$ zizi, a:gi $\sim$ gigi
b. 3o:fia $\sim$ fifi, jo:zef $\sim$ dodo:
c. kova:tf koko:, sabo: $\sim$ sasa

Some cases are ambiguous in their choice of the diminutive formation process, i.e. we cannot decide whether they exemplify truncation plus the ending $i$ or redu-

17. Finally, in some cases only the vowels differ: monda 'legend' $\sim$ mendemonda, gaz 'weed' $\sim$ gizgaz, gazof 'weedy' gizefgazof. 
plication, but we see no reason why the choice should be made anyway: eg lilia lili, vivien vivi.

We end this survey of bisyllabic diminutive forms by listing further examples that are totally idiosyncratic, (16a), involve hapax endings, (16b), metathesis, ${ }^{18}$ (16c), loan stems, (16d), or diminutives that do not have a phonetically similar nondiminutive form, (16e).

(16) Idiosyncratic diminutives

a. førf $\sim$ furi, margit $\sim$ mantsi, lø:rints $\sim$ lo:tsi

b. labda 'ball' $\sim$ lasti, ${ }^{19}$ ta: $\int k a$ 'bag' $\sim$ taco', disko: 'discotheque' $\sim$ dizi, bitsikli 'bicycle' bitsaj, repylø: 'airplane' repzaj, klas: 'cool' $\sim$ klafa or kafa

c. forint 'HUF' $\sim$ frontfi, bala:3 $\sim b a_{3} i$

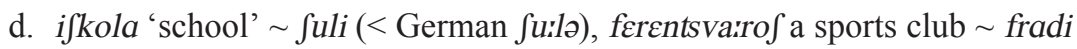
(< German frantsftat Ferencváros, district of Budapest), ba:c 'elder brother' $\sim$ braco: ( $<$ Slovak brat), medve 'bear' $\sim$ matsko: (< Slovak matsko, diminutive of matej), or: 'nose' $\sim$ no:zi ( $<$ Yiddish noz 'nose')

e. pitsi 'small', reco: 'loo', duci 'jail', sycø: 'pouch', tfatfi 'donkey', go: $f i$ 'brains', hajtfi 'sleep', buli 'party', patfi 'high five', tsuntsi 'cunt', bukfi 'head', muki or mukso: 'pal'.

\subsection{Trisyllabic diminutives}

Most templatic diminutives are bisyllabic, a very little set is monosyllabic. There also is a group of diminutive forms that are three syllables long. These we list in (17).

(17) The trisyllabic diminutive template

a. kuca 'dog' kuculi, farok 'tail' farkintsa

b. pitsi 'small' $\sim$ pitsuri, ? pinduri 'small'

c. apa 'father' aputsi, ana 'mother' aputsi, baba 'baby' babutsi

d. aif 'bed' a:fiko', ha:z 'house' ha:ziko', la:da 'box' la:diko', la:b 'leg' la:biko', has 'belly' hafiko', an:a(?) aniko:

For the patterns in (17a) we have found single examples. The word patfuli 'patchouli', which is not a diminutive etymologically, also has sniffy connotations, probably due to its sound shape. Similarly, the tiny muflitsa 'fruit fly' is

18. In fact, bazi may also be seen as an example of contiguity violation, the deletion of -la:- in the middle of the string.

19. Apparently this is a diminutive of Elastik, a brand name. 
often muflintsa. The first two examples in (17c) could be analysed as apa $>a p u$ $>$ aputsi, but the ending -tsi enforces a bisyllabic template in all other cases (cf. $j \varepsilon n \varnothing \sim j \varepsilon n t s i$, this is a possibility even for apa $\sim a p t s i)$. Finally, the ending -iko: in (17d) apparently can only be added to stems containing $a$ or a:. If this stem is longer than one syllable, it is truncated, hence -iko: too enforces a trisyllabic template.

\section{Diminutives and their roots}

If we compare the phonetic form of a diminutive and its root we can observe that on the whole they are much more different from each other than other types of words and forms derived from them. In some cases diminutive forms happen to match the template by the simple addition of an ending (e.g. Syn 'hedgehog' Syni, ha:z 'house' ha:ziko', tfaj 'gal' tfajsi, ja:nof ja:nofka, fyløp fyløpke). In the majority of the cases, however, diminutive formation involves the loss of a smaller or larger portion of the base word, and it may also involve metathesis and other highly idiosyncratic phenomena, as discussed in the preceding section. Thus, as a category, diminutives are the least similar to their base in the whole system of Hungarian morphology.

If we look at the semantic relationship between a word and its diminutive form, we also find that this relationship is much looser than in the case of most other suffixations. Diminutives often have strictly defined usages that cannot be derived from their form. The diminutive $\varepsilon g \int$ for $\varepsilon g e: \int e$ : $g \varepsilon d r \varepsilon$ can only be used as a reaction to someone sneezing, although the "full form" is also used before drinking, like 'cheers' (the compositional meaning of the word is 'to your health'). The diminutives tøri 'history.DIM', føtsi 'geography.DIM', or bios 'biology.DIM' can only be used as school subjects, and we have seen the split in the meanings of loki and loksi above.

Coupled with the fact that the selection of the dozens of different diminutive endings, the shortening or absence thereof of the first vowel of the stem, the simplification or not of the consonantal interlude between the two vowels, the palatality of the consonant before the diminutive ending are largely unpredictable, we must conclude that diminutive forms are lexical items that are not phonologically related to their base word, i.e. they are suppletive forms.

To sum up, we collect the differences of "regular" suffixation and templatic diminutive suffixation in a table in (18). ${ }^{20}$

20. The concatenative diminutive suffixes $-k \varepsilon /-k a$ and $-(V) t f k \varepsilon /-(V) t f k a$ are counted as regular as discussed above. 
(18) Differences of diminutive and non-diminutive suffixation

\begin{tabular}{|l|l|l|}
\hline & regular suffixation & diminutive suffixation \\
\hline suffixation & mainly agglutinative & mostly two syllable template \\
\hline root alternations & one vowel may be deleted & $\begin{array}{l}\text { radical: longer sequences can } \\
\text { be deleted }\end{array}$ \\
\hline productivity & mainly productive & $\begin{array}{l}\text { semi-productive: gaps cannot } \\
\text { be predicted }\end{array}$ \\
\hline $\begin{array}{l}\text { shape of the suffixed } \\
\text { forms }\end{array}$ & determined & $\begin{array}{l}\text { not determined which dim. } \\
\text { suffix will be applied \& } \\
\text { random palatal/labial C } \\
\text { insertion }\end{array}$ \\
\hline V harmony in suffix & harmonizing & $\begin{array}{l}\text { not harmonized at all } \\
\text { (weak tendency for } \\
\text { counter-harmony) }\end{array}$ \\
\hline $\begin{array}{l}\text { link between root } \\
\text { and suffixed form }\end{array}$ & semantically transparent & $\begin{array}{l}\text { weak: special pragmatics } \\
\text { \& referential differences for } \\
\text { names }\end{array}$ \\
\hline
\end{tabular}

Our claim that the connection between a diminutive form and its "base" is looser than in the case of other types of suffixation is further corroborated by the way diminutives trigger front/back harmony. This is what we discuss now.

\section{Diminutives and harmony}

The endings of diminutive forms are unlike suffixes in that they do not have front/ back variants. This is not surprising in the case of endings containing $i$ (and there are no diminutive endings containing $e$ :), but it is unusual for those with a back vowel $(u, o:, a)$ or $\varepsilon$. These vowels do not occur in any other invariant suffix. Examples are given in (19).

(19) Diminutive endings do not harmonize

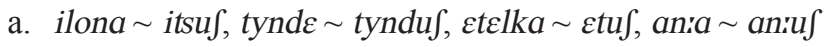

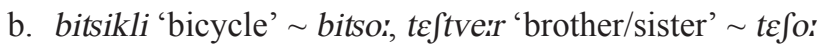
c. fekete 'black' $\sim$ feka, katalin $\sim$ kata
d. kol(:)ergium 'dorm' koles, ka:roj kares, kalauz 'conductor' $\sim$ kal:er
e. katalin $\sim$ kato', telefon 'telephone' $\sim$ telo: 
Although there exist the archaic diminutive endings - $-\varnothing$ : beside $-O$ : and $-\varepsilon$ beside $-a$ (cf. footnote 13), they are not used productively: telefon 'phone' gives telo: (not *telø:, cf. sel 'cut' sel-ø: 'cut-PART' vs fal 'devour' fal-o: 'devour-PART') and $\varepsilon t \varepsilon l k a \sim \varepsilon t a($ not $* \varepsilon t \varepsilon$ ). It seems that truncating diminutive endings are more independent of vowel harmony than other suffixes. Although neither -o: nor $-a$ is added to a stem containing a front rounded vowel (which are among the less frequent members of the vowel inventory anyway), almost any front vowel may exhibit antiharmonic behaviour with diminutive endings.

The fact that diminutive endings do not harmonize is relevant, because otherwise suffixes in Hungarian either alternate according to front/back harmony or contain a neutral vowel, $i, i$, or $e^{\prime}-$ as has been mentioned above, the low neutral vowel, $\varepsilon$, does not occur in invariant suffixes. There do exist some endings that are invariant and contain nonneutral vowels, but these can be shown not to be suffixes, because they can be added to coordinate structures: e.g. -fe:le 'kind of' ( $f a$ vaf bokorfe:le 'kind of tree or shrub'), -sery(:) 'type' (fa e: $\int$ bokorsery(:) 'tree and shrub-like'), -kor (\%ne: $f$ vaf øtkor 'at four or five'). ${ }^{21}$ Since many of the diminutive endings contain nonneutral vowels and yet are invariant, they clearly stick out of the system of suffixes. The two suffixes that show synchronic harmonic alternation, $-k \varepsilon / k a$ and $-(V) t f k \varepsilon /(V) t f k a$, are exactly the ones that do not squeeze their output into a template, hence do not truncate it, and are concatenated just like any "normal" suffix of Hungarian.

Another indication that diminutive forms do not contain suffixes is the harmonic properties of these items. Harmonic uniformity does not apply to diminutive forms, as the examples in (20) show.

(20) Diminutives defy harmonic uniformity
a. Sima:-ra 'smooth-SUBL' Sim-ist-va 'make smooth-PART'
b. Simon-ra 'Simon-SUBL' Simi-re 'SimonDIM-SUBL'
c. jo:3ef-re 'Joseph-SUBL' jo:zi-ra 'JosephDIM-SUBL'22
d. ka:roj-ra 'Charles-SUBL' kares-ra/re 'CharlesDIM-SUBL'
e. testve:r-re 'brother/sister-SUBL' $\sim$ tefo'-ra 'brother/sisterDIM-SUBL'

The words in (20a) are a reminder, they show the effect of harmonic uniformity: the participial suffix takes its back variant, -va, because the root, Jima, which turns into fim-after truncation, is back harmonic. After any number of neutral suffixes following this root a variable suffix attached to a word containing this root will be back. The name fimon in (20b) is also back harmonic, as the untruncated form shows. After diminutive truncation, however, Simi becomes front harmonic. In $(20 \mathrm{c})$ we see a root that is front-harmonic because of the height effect: the back

21. Some speakers will not accept this form, only ne:fkor vaf øtkor. For them -kor is an exceptional non-diminutive suffix with an invariant back vowel.

22. This example was pointed out by Catherine Ringen. Thanks! 
vowel of the first syllable is followed by the low neutral vowel, $\varepsilon$. In the diminutive form, this vowel is truncated and replaced by the high neutral vowel, $i$, the resulting diminutive name is back-harmonic, like a morphologically simplex Bi root would be. (20d) exemplifies the contrary situation: the back harmonicness of the stem is lost once its final vowel is replaced by $\varepsilon$ : the result is variable. Finally, in (20e) the diminutive of teftverr, which is front harmonic, turns out to be back harmonic, as it ends in the back vowel provided by the diminutive template, again defying harmonic uniformity. In these examples we omit the hyphen before the diminutive ending to visualize our claim: truncating diminutive forms are morphologically simplex. If a word like fimi, jo:zi, or tefo: is morphologically simplex, then we predict that their harmonic class is not inherited from their root, since they do not have a root that is different from them. That is, the root of Jimi is Simi, and therefore this word belongs to the front harmonic class like any other bisyllabic root with two neutral vowels, as the polysyllabic split predicts.

Diminutive forms are also different from other suffixed words in that it is possible to apply different diminutive formation processes to diminutives over and over again. This is not normally the case with other suffixes: ${ }^{23}$ a plural, a case, or a person-marking suffix cannot be added to a word that already has another instance of the semantically same suffix. With diminutives, on the other hand, this is very common: e.g. ma:ria $>$ mari $>$ marika $>$ marika:tfka, an:a $>$ an:uf $>n u \int i>n u \int i k a$, e:va $>$ e:vi > vitsa > vitsa:tfka, la:slo: > latsi/latsa > latsko: > latsko:tfka.

\section{Conclusions}

Most words of Hungarian are subject to harmonic uniformity, that is, whether a word takes the front or back variant of a suffix does not depend on the vowels of the word only the harmonic class of the root, that is, the first morph in the word. Needless to say, the harmonic class of the root is in most cases predictable from its vowel(s), although there is a sizable set of antiharmonic roots. We may take these to be exceptions to harmony. This exceptionality is inherited in the whole paradigm.

Templatic diminutive forms in Hungarian, however, appear not to be subject to harmonic uniformity. Thus, a diminutive form does not "inherit" the harmonic class of the word it is the diminutive of. We submit that this is because templatic diminutive forms behave like morphologically simplex items of the lexicon. Thus these diminutive forms are exceptions to the overall pattern of harmonic uniformity, which normally preserves the exceptional antiharmonic property of a root.

23. A reviewer points out that the adjectival suffix $-i$, may be followed by another adjectival suffix, -a/Ef: e.g. harts 'fight' > hartsi 'related to a fight' > hartsiaf 'militant'. These, however, are two different suffixes semantically: although both could be glossed as 'ADJ', hartsi and hartsof only share their word category, adjective. 


\section{References}

Alber, Birgit \& Arndt-Lappe, Sabine. 2012. Templatic and subtractive truncation. In Jochen Trommer (ed.). The Morphology and Phonology of Exponence, 289-325. Oxford: Oxford University Press.

Benua, Laura. 1995. Identity effects in morphological truncation. In Beckman, Jill, Urbanczyk, Susan \& Dickey, Laura Walsh (eds.). Papers in Optimality Theory, 77-136. University of Massachusetts Occasional Papers in Linguistics 18.

Blaho, Sylvia \& Szeredi, Dániel. 2013. Hungarian neutral vowels: A microcomparison. Nordlyd 40(1): 20-40. $<$ http://dx.doi.org/10.7557/12.2499>.

Forró, Orsolya. 2012. Ingadozás a magyar elölségi harmóniában: Szempontok a variabilitás szinkróniájának és diakróniájának feltárásához és értelmezéséhez. Doctoral dissertation, Pázmány Péter Catholic University, Piliscsaba.

Hayes, Bruce \& Londe, Zsuzsa Cziráky. 2006. Stochastic phonological knowledge: The case of Hungarian vowel harmony. Phonology 23: 59-104.

Kiefer, Ferenc \& Ladányi, Mária. 2000. A szóképzés. In Kiefer, Ferenc (ed.). Strukturális magyar nyelvtan 3: Morfológia, 137-164. Budapest: Akadémiai Kiadó.

Kontra, Miklós \& Ringen, Catherine. 1986. Hungarian vowel harmony: The evidence from loanwords. Ural-Altaic Yearbook 58: 1-14.

Patay, Fanni Zsófia. 2015. Reduplikációs típusok és mintázatok: A magyar ikerszók optimalitáselméleti elemzése. BA thesis, Theoretical Linguistics Programme, Eötvös Loránd University, Budapest.

Rebrus, Péter. 2000. Morfofonológiai jelenségek. In Kiefer, Ferenc (ed.). Strukturális magyar nyelvtan 3: Morfológia, 763-947. Budapest: Akadémiai Kiadó.

Rebrus, Péter. 2005. Hogyan inflektál a magyar? In Gervain, Judit, Kovács, Kristóf, Lukács, Ágnes, \& Racsmány, Mihály (eds.). Az ezerarcú elme, 56-67. Budapest: Akadémiai Kiadó.

Rebrus, Péter \& Törkenczy, Miklós. 2015. Monotonicity and the typology of front/back harmony. Theoretical Linguistics 41(1-2): 1-61.

Siptár, Péter \& Törkenczy, Miklós. 2000. The Phonology of Hungarian. Oxford: Oxford University Press.

Sóskuthy, Márton. 2012. Morphology in the extreme: Echo-pairs in Hungarian. In Kiefer, Ferenc \& Bánréti, Zoltán (eds.). Twenty years of theoretical linguistics in Budapest, 123-143. Budapest: Tinta.

Törkenczy, Miklós. 2011. Hungarian Vowel Harmony. In Oostendorp, Marc van, Ewen, Colin J., Hume, Elizabeth \& Rice, Keren (eds.). The Blackwell Companion to Phonology, Volume V, 2963-2989. Malden, Mass. \& Oxford: Wiley-Blackwell.

Törkenczy, Miklós, Szigetvári, Péter \& Rebrus, Péter. 2013. Harmony that cannot be represented. In Brandtler, Johan, Molnár, Valéria \& Platzack, Christer (eds.). Approaches to Hungarian, 229-252. Volume 13: Papers from the 2011 Lund conference. John Benjamins.

van de Weijer, Jeroen. 1989. The formation of diminutive names in Hungarian. Acta Linguistica Hungarica 39: 353-371. 